\title{
Strategi Pemulihan Pasar Badung Sebagai Daya Tarik Wisata Di Kota Denpasar
}

Ni Made Mei Widiari a, 1, I Nyoman Sunarta a, 2

${ }^{1}$ widiarimeiiwidiari@yahoo.co.id,2nyoman_sunarta@unud.ac.id

a Program Studi S1 Destinasi Pariwisata, Fakultas Pariwisata,Universitas Udayana, Jl. Dr. R. Goris, Denpasar, Bali 80232 Indonesia

\section{Abstract}

This research is done in one of the largest traditional market in Denpasar, namely is Badung Market. Badung Market located on Gajah Mada street, its about $1 \mathrm{Km}$ to the West of the Catur Muka Statue, in Denpasar Downtown. This research aims to determine how the recovery strategy tourism of Badung Market as a tourist attractions. This research was analyzed by the concept of a tourist attraction, and also using the concept of markets and traditional markets. After that, this research using the qualitative research of methodologies. This data was obtained from interviews of market management and direct observations in Badung Market.

The damage that occurred in Badung Market that will do by recovery strategy. This aims to rebuild market buildings that was broke. This process requires several stage, namely are: physical intervention, rehabilitation of economic and social/institusional revitalotations.

Post-fire made the biggest market in Denpasar this being lost daily activities. While this relokalisasi Badung market is still running. The damages that occur in the Badung Market will now do the recovery strategy, aims to rebuild the market buildings that have been damaged.

Keyword: market, the recovery strategy, tourist attractions.

\section{PENDAhuluan}

Pariwisata merupakan salah satu sektor andalan di Indonesia sebagai penyumbang devisa setelah migas (minyak dan gas). Pariwisata tidak hanya terjadi di luar negeri, bahkan sudah sejak lama masuk ke Indonesia khususnya Pulau Bali.

Bali merupakan salah satu pulau yang terkenal akan pariwisata nya, Bali terdiri atas delapan kabupaten, dan Denpasar sebagai Ibu Kota Provinsi Bali. Bali memiliki berbagai daerah tujuan wisata dengan potensinya masing-masing. Saat ini Bali terkenal akan keindahan sawah (wisata perdesaan), pantai (sunset dan sunrise), air terjun, gunung, danau, spiritualisme, kebudayaan, wisata perkotaan dan wisata belanja. Salah satu kegiatan pariwisata yang sedang booming saat ini adalah wisata belanja. Wisata belanja adalah kegiatan wisata yang dilakukan dengan mengunjungi tempat tertentu untuk membeli barang maupun jasa yang disediakan. Wisata belanja lebih ditonjolkan di daerah perkotaan, karena kelengkapan akomodasi yang ada di daerah perkotaan cenderung lebih memadai untuk menjadikan wisata belanja, seperti pusat oleholeh, kuliner, kerajinan, pameran, dan lain sebagainya. Salah satu wisata belanja yang masih tradisional sampai saat ini adalah pasar Badung. Pasar Badung adalah salah satu pasar tradisional terbesar di Bali yang berlokasi di Denpasar yang menjadi tempat yang banyak dikunjungi oleh kalangan turis domsestik ataupun asing. Tanggal 29 Februari 2016, tepatnya pada akhir Bulan Februari, kobaran api telah membakar kios-kios yang ada di pasar Badung. Beberapa issu pun bermunculan terkait permasalahan yang terjadi. Hampir semua dari pedagang yang memiliki usaha dalam kios di Pasar Badung hanya bisa berpangku tangan dan menangis melihat kioskios mereka lenyap dilalap oleh kobaran api yang begitu besar. Kegiatan berjualan pun seketika terhenti pasca kebakaran. Wisatawan mulai enggan untuk berkunjung ke Pasar Badung karena merasa kurang nyaman akan keadaan Pasar Badung yang sekarang ini dimana penataan para pedagang yang berjualan disekitarnya menjadi berdesakan dengan pedagang-pedagang lainnya satu sama lain dan bangunan-bangunan bekas terbakar pun menjadikan pasar tersebut menjadi sangat kumuh. Hal tersebut menjadi faktor yang dapat menurunkan citra baik dari Pasar Badung, serta dapat menurunkan taraf perekonomian pedagang.

Oleh karena itu dalam jurnal ini mengkaji: bagaimana strategi pemulihan pasar Badung sebagai daya tarik wisata di Kota Denpasar?

\section{TINJAUAN PUSTAKA}

Jadi telaah hasil penelitian sebelumnya dalam penelitian ini yang dilakukan oleh Ucang Sukriswanto (2012), yang meneliti tentang "Analisis Kelayakan Revitalisasi Pasar Umum Gubug Kabupaten Grobogan". 
Adapun beberapa konsep yang digunakan dalam penelitian ini adalah:

1. Konsep Daya Tarik Wisata (Cooper dkk, 1995 : 81), konsep tersebut yang dimaksudkan dalam penelitian ini untuk mengetahui atraksi-atraksi unik yang dimiliki oleh pasar Badung untuk menarik para wisatawan sebelum terjadinya kebakaran dan pasca kebakaran. Atraksi yang dimiliki oleh pasar Badung sebagai daya tarik wisata yang sangat disukai oleh wisatawan adalah kegiatan tawar menawar antara para pedagang dengan pembeli, adanya ciri unik yaitu tukang suun (orang yang menjunjung barang belanjaan para pembeli), dan adanya sungai yang luas (Tukad Badung) serta adanya bangunan kuno yang masih berdiri kokoh di pasar Badung dan disepanjang jalan Gajah Mada (kawasan heritage) yang dapat menarik wisatawan untuk berkunjung ke pasar Badung.

2. Konsep Revitalisasi (Danisworo, 2000), konsep ini berkaitan dengan strategi pemulihan pasar Badung sebagai daya tarik wisata di Kota Denpasar.

3. Konsep Pasar Tradisional (Peraturan Presiden Republik Indonesia No. 112 tahun 2007), konsep pasar tradisional dalam penelitian ini untuk memberikan pengertian mengenai pasar tradisional dan berkaitan dengan pasar Badung sebagai salah satu pasar tradisional terbesar di Kota Denpasar yang dijadikan salah satu daya tarik wisata di Kota Denpasar.

\section{METODE}

Penelitian ini dilakukan di pasar Badung yang bertempat di Jalan Gajah Mada Kota Denpasar. Kemudian jenis data yang digunakan dalam penelitian ini adalah data kualitatif. Data kualitatif yang dimaksudkan dalam penelitian ini berupa strategi pemulihan pasar Badung sebagai daya tarik wisata di Kota Denpasar. Sumber data yang dipergunakan yaitu data primer dan data sekunder. Data primer seperti data/informasi dari hasil wawancara dengan informan terkait. Sedangkan data sekunder dalam penelitian ini berupa sejarah Pasar Badung, kunjungan jumlah wisatawan pasca kebakaran, serta data geografis dan demografis Pasar Badung sebagai daya tarik wisata.

Pengumpulan data dalam penelitian ini dilakukan dengan observasi (Arikunto, 2002), wawancara (Esterberg dalam Sugiyono, 2013 : 231) dan studi kepustakaan (Sugiyono, 2012). Sedangkan teknik penentuan informan menggunakan teknik purposive sampling. Teknik analisis data dilakukan melalui proses analisis deskriptif kualitatif. Aktivitas tersebut adalah reduksi data, penyajian data, dan penarikan simpulan, (Sugiyono, 2007).

\section{HASIL DAN PEMBAHASAN}

Salah satu pasar tradisional terbesar di Kota Denpasar adalah pasar Badung. Dimana pasar ini sebelum terjadinya kebakaran memiliki kondisi yang sangat menarik untuk dikunjungi oleh wisatawan domestik maupun wisatawan mancanegara. Tatanan bangunan tua menjadikan wisatawan sangat tertarik untuk mengunjungi pasar ini. Pasar Badung yang buka setiap hari dengan waktu 24 jam, menjadikan pasar ini selalu ramai dikunjungi wisatawan ataupun pembeli. Wisatawan yang datang biasanya pagi hingga sore. Selain hal tersebut, hal biasa yang terjadi di pasar tradisional lainnya adalah proses jual beli antara pedagang dengan pembeli. Setelah membeli barang yang diperlukan, biasanya terdapat tukang suun yaitu orang yang akan menjunjung barang belanjaan yang sudah dibeli. Biasanya orang-orang yang menjunjung barang belanjaan akan dibayar mulai dari Rp. 2000 sampai dengan Rp. 20.000, tergantung dari banyaknya belanjaan yang akan dijunjung. Hal tersebut sangat unik menurut beberapa wisatawan mancanegara yang berkunjung ke pasar Badung. Pemandangan yang sangat bagus juga bisa dilihat wisatawan dari lantai 4, seperti melihat sungai (tukad Badung) yang begitu luas juga menjadi daya tarik tersendiri dari pasar Badung, karena dari atas kita dapat melihat beberapa orang yang memancing di sungai tersebut. Pasar Badung yang memiliki bangunan yang begitu unik serta dulunya sangat ramai dikunjungi oleh wisatawan kini menjadi sepi, selain itu keadaan Pasar Badung saat ini tidak ada aktivitas jual belinya sama sekali. Begitupula dengan pariwisata yang dulunya berkembang di Pasar Badung kini menjadi sepi, hanya aktivitas pariwisata di Pasar Kumbasari dan di kawasan Gajah Mada saja yang masih berlangsung hingga saat ini. Pasar Badung yang berdiri begitu besar dengan bangunan yang sangat kokoh kini berubah menjadi rusak karena terjadinya kebakaran.

Dalam revitalisasi ini dilakukan untuk memperbaiki bangunan Pasar Badung karena telah terjadi kebakaran. Strategi pemulihan 
pasar tradisional ini dilakukan dengan melalui beberapa tahap dan waktu pemulihan (pembangunan kembali) dan meliputi beberapa hal sebagai berikut :

\section{a. Intervensi Fisik}

Intervensi fisik dalam penelitian ini perlu dilakukan karena kawasan pasar Badung sangat erat kaitannya dengan kondisi visual. Saat ini intervensi fisik dari Pemerintah untuk pasar Badung adalah bantuan anggaran untuk pembangunan kembali pasar Badung, anggaran yang diperlukan tidaklah sedikit, dan bantuan anggaran yang dirujuk ini merujuk kepada Kementrian Perdagangan Republik Indonesia, Pemerintah Kota Denpasar, dan PD Pasar lainnya.

Pasar tradisional yang dulunya biasa saja, selanjutnya akan ditetapkan menjadi pasar tradisional SNI. Walaupun dirubah menjadi pasar tradisional SNI, kualitas pasar ini akan ditata seperti semula. Untuk para pedagangnya pun akan ditetapkan dengan jumlah yang sama. Kegiatan jual-beli dengan tatanan dagangan pun akan ditetapkan sama. Aktivitas pariwisata kedepannya juga akan masih tetap dijalankan, karena pariwisata sudah sejak dulu terjadi di pasar Badung.

\section{b. Rehabilitasi Ekonomi}

Rehabilitasi ekonomi pasar Badung masih dalam fase/tahapan. Rehabilitasi ekonomi ini sama dengan tahapan recovery ekonomi, dalam tahapan ini pemerintah melakukan pemberian tempat sementara di ExTiara Grosir yang saat ini disebut sebagai Badung Cokroaminoto. Apabila pembangunan telah selesai dibangun, maka mereka akan menempati kembali bangunan yang telah dibangun kembali di Pasar Badung dan dengan jumlah pedagang yang sama. Jadi para pedagang-pedagang yang direlokalisasikan ke Badung Cokroaminoto tersebut akan ditarik kembali ke pasar Badung Gajah Mada setelah bangunan tersebut selesai. Hal tersebut dilakukan untuk mendorong berlangsungnya kegiatan atau aktifitas sosial sehingga masih tetap mempertahankan kegiatan ekonomi dari para pedagang-pedagang.

\section{c. Revitalisasi Sosial/Institusional}

Kegiatan revitalisasi sosial atau institusional di pasar Badung tersebut memberi dampak positif serta mampu meningkatkan kehidupan sosial masyarakat.
Tahapan sosial/institusional sudah berlangsung sesuai dengan data pedagang yang sudah tercatat sebelum kebakaran sehingga proses pendataan pedagang sudah selesai. Tahapan berikutnya persiapan anggaran yang diperlukan dan perencanaan selanjutnya dari Pasar Badung, pembongkaran Pasar Badung, kemudian penyusunan anggaran, dan pembangunan pasar yang masih dalam proses.

Saat ini proses revitalisasi Pasar Badung masih banyak yang perlu diurus. Proses revitalisasi akan mulai dijalankan setelah anggaran dana tercukupi, perencanaan sketsa dari pasar yang akan dibangun kedepannya seperti apa, kemudian perobohan bagunan lama pasar Badung. Proses pemulihan Pasar Badung kedepannya masih memerlukan banyak waktu, sekitar 3 tahun sampai 4 tahun dan membutuhkan biaya yang sangat banyak.

\section{SIMPULAN DAN SARAN}

Pasca kebakaran menjadikan pasar terbesar di Kota Denpasar ini menjadi kehilangan aktivitas kesehariannya. Sementara ini relokalisasi Pasar Badung masih berjalan. Kerusakan-kerusakan yang terjadi di Pasar Badung kini akan dilakukan proses strategi pemulihan (revitalisasi). Revitalisasi ini bertujuan untuk membangun kembali bangunan pasar yang telah rusak. Proses revitalisasi ini memerlukan beberapa tahapan, yakni diantaranya adalah: (a). intervensi fisik, (b). rehabilitasi ekonomi, dan (c). revitalisasi sosial/institusional.

Bangunan Pasar Badung yang sudah tidak layak dipakai lagi, mengharuskan Pemerintah dan lembaga-lembaga lainnya yang bersangkutan agar segera merevitalisasi bangunan Pasar Badung tersebut. Anggarananggaran yang dibutuhkan agar segera disediakan. Perencanaan bangunan ulang pun seharusnya secepat mungkin dibuat. Hal tersebut dikarenakan Pasar Badung berada di pusat kota Denpasar dan Pasar Badung merupakan salah satu tempat yang dijadikan sebagai city tour. Pasar ini juga menjadi salah satu daya tarik di Kota Denpasar yakni sebagai wisata belanja untuk wisatawan domestik maupun wisatawan mancanegara. Selain untuk pariwisata, pasar ini menjadi tempat untuk kegiatan perekonomian dari para pedagang. 


\section{DAFTAR PUSTAKA}

Arikunto, S. 2002. Prosedur Penelitian, Suatu Pendekatan Praktek. Jakarta: PT Rineka Cipta.

Danisworo, Mohammad \& Widjaja Martokusumo. 2000. "Revitalisasi Kawasan Kota Sebuah Catatan dalam Pengembangan dan Pemanfaatan Kawasan Kota". www.urdi.org (urban and reginal development institute.

Pendit, Nyoman S. 1990. Ilmu Pariwisata Sebuah Pengantar Perdana. Jakarta:T. Pradnya Paramita.

Peraturan Presiden Republik Indonesia No. 112 tahun 2007

Sugiyono. 2007. Metode Penelitian Pendidikan pendekatan Kuantitatif, Kualitatif dan R\&D. Bandung : ALFABETA.

Sugiyono. 2012. Memahami Penelitian Kualitatif. Bandung : ALFABETA

Sugiyono. 2013. Metode Penelitian Kuantittatif Kualitatif dan R\&D. Bandung: ALFABETA.

Sukriswano, Ucang. 2012. "Analisis Kelayakan Revitalisasi Pasar Umum Gubug Kabupaten Grobogan. Tesis. Universitas Diponegoro Semarang.

UU RI No, 10 Tahun 2009 Tentang Kepariwisataan.

Wiryomartono, Bagoes P. 1995. Seni Bangunan dan Seni Biakota di Indonesia: Kajian mengenai konsep, struktur dan elemen fisik kota sejak peradabanHindu Budha, Islam hingga sekarang. Jakarta : PT. Gramedia Pustaka Utama. 